\title{
Lexis
}

Journal in English Lexicology

13 | 2019

Lexicon, Sensations, Perceptions and Emotions

\section{The language of mental pain: feel like, feel as if}

\section{Catherine Paulin}

\section{OpenEdition}

\section{Journals}

Electronic version

URL: http://journals.openedition.org/lexis/2639

DOI: $10.4000 /$ lexis.2639

ISSN: 1951-6215

\section{Publisher}

Université Jean Moulin - Lyon 3

\section{Electronic reference}

Catherine Paulin, «The language of mental pain: feel like, feel as if », Lexis [Online], 13 | 2019, Online since 14 March 2019, connection on 01 May 2019. URL : http://journals.openedition.org/lexis/2639 ; DOI : $10.4000 /$ lexis.2639

This text was automatically generated on 1 May 2019.

\section{(c) (i) (9)}

Lexis is licensed under a Creative Commons Attribution-NonCommercial-NoDerivatives 4.0 International License. 


\title{
The language of mental pain: feel like, feel as if
}

\author{
Catherine Paulin
}

\section{Introduction}

1 The International Association for the Study of Pain [1994] provided the following definition of pain: "An unpleasant sensory and emotional experience associated with actual or potential tissue damage, or described in terms of such damage." The relation of causation between an actual or potential tissue damage and the experience of pain does not apply, at least in most cases, to mental pain. On the contrary, the inability, or at least the difficulty, to communicate verbally about pain, applies to physical and even more so to mental pain. On the one hand, mental suffering comes with having a mind and can be conceptualized as a subcategory of state. Such is the case in the following utterance: "I am a shrimp at the bottom of the sea" used to convey a state of profound depression. On the other hand, mental pain can be conceptualized as a subjective experience, as in J. Frame [2009: 18]:

(1) I felt myself dropping as if a trap door had opened into darkness ${ }^{1}$

2 The language of mental pain reveals how difficult it is to verbalize our sensations, emotions, feelings, subjective states. The difficulty does not necessarily lie in the fugacity of sensations, emotions or feelings. For A. Damasio [1999: 42] "the term feeling should be reserved for the private, mental experience of an emotion, while the term emotion should be used to designate the collection of responses, many of which are publicly observable" given that mental pain often is a lasting experience or a subjective state. A. Damasio [1994: 149-150] identifies varieties of feelings: the first variety is based on emotions such as happiness, sadness, anger, fear, etc. and engenders state responses. The subject experiencer feels happy, sad, angry, fearful, etc. A second variety of feelings is based on emotions that constitute variations of the first type: 
[...] euphoria and ecstasy are variations of happiness; melancholy and wistfulness are variations of sadness; panic and shyness are variations of fear. This second variety of feelings is tuned by experience, when subtler shades of cognitive state are connected to subtler variations of emotional body state. [Damasio 1994: 149-150]

In Damasio's approach, these varieties of feelings of basic or more subtle emotions, are universal. This paper will concentrate on feelings of mental pain - which I believe are universal -, on the difficulty there is to translate them into verbal language, on the conceptual patterns and the idiosyncratic variations that are mobilized to communicate the experience of mental pain. The non-conformity between what is felt and its verbal representation leads us to examine the role of the irreal in expressing inner feelings. The term irreal is here to be understood as R. Langacker [1991: 243] defines it: what is "other than (known) reality". He further explains that "[T]he core of known reality is thus surrounded by a much larger region of unknown reality. Included in this region are situations of at least two sorts: those whose reality $\mathrm{C}^{2}$ suspects or contemplates but does not accept as having been established, and those of which he is entirely ignorant." Hence the idea that the irreal enables the subject to conceptualize inner states of experience or feelings, which are real for him, whose existence is not fully established for anyone else and which are difficult to put into words. Mental pain is other than fully apprehended known reality. The conceptualizer has undergone an experience which can only be represented approximately in figurative language. The very reality of mental pain is apprehended by what it is not. C. Lascaratou [2007:18] explains that pain is twodimensional: internal and invisible, external and behavioral: "Most importantly, people also claim their pain verbally. By means of these verbalizations, they aim at expressing, describing, qualifying their pain experience." Pain includes an internal experiential state of pain and an external accompaniment of the experience, both verbal and non-verbal. C. Lascaratou [2007: 25] asserts the double role of verbal manifestations of pain:

[...] by providing descriptive accounts, they may inform others and, for the sufferer, they are representations reflecting his own experience, i.e. expressions rather than descriptions. Thus, a description is other-oriented and informative, whereas an expression is self-oriented.

The conceptualizer opts for irreal states or events to express his or her pain, which he or she does not describe. The irreal is located outside the immediate reality of the conceptualizer. For Langacker [1991], the irreal can either be unknown reality, or, that part of reality which is not accepted or conceptualized as being factual. The irreal can only be verbal whereas the real has an existence of its own, outside verbal representation. As R. Langacker [1991: 243] explains:

A situation does not belong to reality or irreality on the basis of how the world has actually evolved, but depends instead on whether the conceptualizer knows and accepts it as being part of that evolutionary sequence.

With feel like and feel as if, the conceptualizer uses what he or she does not construe as factual, what belongs to his or her conceptual irreal, to express his or her pain. The real, by contrast, has to do with the certitude a speaker has about a state, an event. Mental pain is expressed by approximation, by drawing comparisons with what it is not, with what is not recognized or accepted as real.

6 The initial hypothesis is that there is no direct linguistic expression of mental pain - and more generally of emotional experience or state. The central question can be phrased as follows: what is the role of the irreal in the intermediary step of conceptualization? This 
broad question will be narrowed down to: 1 . The analysis of the construction feel like and feel as if; 2. The conceptual role of the external notions mental pain is associated with. This corpus-based study relies on autobiographical sub-genres (an autobiographical novel, auto-fiction, and a journal): Faces in the Water and An Autobiography by Janet Frame, Shoot the Damn Dog by Sally Brampton, The Journals of Sylvia Plath, and Darkness Invisible: A Memoir of Madness by William Styron. Additional contextualized excerpts from the $\mathrm{BNC}^{3}$ are added.

\section{Feel like, feel as if}

7 The constructional polysemy of the lexical verb feel is studied in C. Paulin [2003]. The present study addresses the emotion schema representing the emotional state human beings experience when they are in (mental) pain, defined as a complex experience, subjective and difficult to quantify. Pain-related terms or expressions are often figurative: language describes experiences of (physical and mental) pain, but it does not name them. There is no literal expression of pain. Whether mental pain is less prototypical - in the sense of E. Rosch [1978] - than physical pain in the way the notional domain of pain is apprehended is not relevant for the analysis. The interest lies in the fact that language helps constitute emotions, as shown by M. Gendron, K. A. Lindquist, L. Barsalou \& L. F. Barrett [2012] who, in an experimental psychology approach, develop the idea that words shape perception in a variety of domains and that emotion words act as a context during emotion perception: "One possibility is that language is just another type of context to add to the list-an internal context in the mind of the perceiver." Findings from cognitive psychology show language does not only help us communicate our emotional perceptions and experiences, it also helps us constitute them. The idea that language shapes our thoughts and experiences goes back to the Linguistic Relativity Hypothesis developed by Whorf. It has long been accepted that sensory and conceptual information play a role in building up conscious experience. In this paper, it is hypothesized that expressions of the irreal guide or even constitute subtle emotional states or experiences such as mental pain. In other words, feeling mental pain does not only get put into words. Verbal expressions get put into feelings. The constructions I feel like or I feel as if include an experiencer that coalesces with the grammatical subject and constitutes the theme of the utterance. The cause of the pain is not expressed and may not even be conscious. The construction focuses on the experiencer, the emotional state or experience for what it is not. Hence the idea that the verbal comparison in like or as if constitutes the emotion. In N. Gisborne's classification of perception verbs [2010: 4-8], feel is in such cases considered as an experiencer verb: feel captures the subject's cognitive ability to experience pain. The way mental pain is conceptualized depends on the comparison variants.

\subsection{Feel like + NP or propositional content}

R. Huddleston \& G. Pullum [2002: 1154] explain that with an NP complement, "like rather than as is used in non-scalar term comparisons of equality". In (2) to (5), the like + NP phrase functions as predicative complement. In order to represent the mental pain that the $I$ endures, a comparison is drawn between the experiencer, the primary term, and negatively connoted entities: $a$ hole in the ground, a heel of the worst sort, a maggot in a 
carcass, hell. The non-scalar comparison established by feel like NP allows metaphorical reasoning. Mapping a hole, a heel (in the sense of a contemptible untrustworthy person), or hell onto the I enables the conceptualizer to create a third space: mental pain, conceptualized as a negative entity. The experiencer is assimilated to the pain he feels. In (2) to (4), like is complemented by [A NP PP]. The whole sequence forms a single NP which is discursively produced to represent mental pain figuratively.

(2) I felt like a hole in the ground. (S. Plath [1971: 16])

(3) I felt like a heel of the worst sort. (S. Plath [1971: 5])

(4) 'If this old body has anything to try with,' Frank gasped. 'Do you know what I feel like? I feel like a maggot in a carcass. I know I'm alive. But everything around me is dead.' 'The body is tougher than you think,' Sister Cooney said. 'It needs driving, that's all. It's a sophisticated kind of machine and, like a machine, you can't afford to let it get rusty or it'll seize up.' (BNC)

In (5), the construction allows the suffering I to be represented as hell. A construction in which hell would be used as a locative as in (5') would not allow the metaphorical mapping. In (5'), the that-content clause functions as direct object of the verb feel, which then expresses cognition rather than perception, sensation, or emotion. Feel like hell is a fixed expression in which mental suffering is conventionally conceptualized as hell, as in (6) in indirect discourse.

(5) I felt like hell. (S. Plath [1971: 43])

(5') I felt (that) I was in hell.

(6) I also hate people to ask cheerfully how you are when they know you're

feeling like hell and expect you to say "Fine". (S. Plath [1971: 177])

In (7) to (10), the complex NP with its expansion [A NP (PP) relative clause] is relevant to the comparison and the inner conceptualization the experiencer makes of mental distress. In (8), you stands for all the I's in mental homes who share a common experience. The core NP refers to a human being (a child, a guest, an angler) whose condition is made precise in the relative clause. Unlike the $I$ in (2) to (4), the $I$ in (7) to (10) is not dehumanized.

(7) I feel like a child who has been forced to eat a strange food in a strange house and who must spend the night there in a strange room with a different smell in the bedclothes and different borders on the blankets, and waken in the morning to the sight of a different and terrifying landscape from the window. (J. Frame [2009: 14])

(8) You felt like a child at an orphanage who has been accepted for adoption and must face, when your new parents call for you, the longing gaze of the deprived people around you. (J. Frame [2009: 45])

(9) But I felt increasingly like a guest who is given every hospitality in a country mansion yet who finds in unexpected moments a trace of a mysterious presence; sliding panels; and at last surprises the host and hostess in clandestine conversations and plottings with mention of poison, torture, death. (J. Frame [2009: 64])

(10) One felt like an angler who discerns the ripple of a rainbow fish which will surely die if it stays in the foul water. (J. Frame [2009: 147])

11 In (11) to (13), like is used with a content clause. Its complement is a complete finite clause, and, in R. Huddleston \& G. Pullum's words [2002: 1158], "it is in competition with as if / though." (11') shows that the manipulation with as if functions. The difference 
between (11) and (11') is acknowledged in terms of language variety and register by the authors. A difference in terms of conceptualization can be added: like being primarily used as a preposition, followed by an NP, its complement is more static, more objectified than the content as if clause. In (11"), the manipulation with as though is not satisfactory given that the enunciator wishes to create an irreal third space, an irreal prison to represent the experiential state of mental pain in which she is trapped. The conjunction though would indicate that the irreal representation of mental pain as a form of imprisonment does not really apply, or does not correspond with the way the conceptualizer wishes to represent it. In (13), prepositional like could be used as in (13'). The representation of mental pain goes from the more irreal/hypothetical in I feel as if I was a guinea pig to the complete superimposition of a guinea pig onto the I in I was a guinea pig. Prepositional like "with an NP as complement is used in non-scalar term comparisons of equality" (R. Huddleston \& G. Pullum [2002: 1154]). In (13') the I establishes a comparison of equality between herself and a guinea pig. She knows that she is not a guinea pig and yet she conceptualizes herself as such. In (13), like is used as a connector which may signal the informal style of the utterance. The comparison is no longer established between two entities - I and a guinea pig - but between the $I$ and "being what the I is (not)". Given that I wasn't a guinea pig, the irreal dimension of the comparison is reinforced. The manipulation in (13") is very similar to (13).

(11) 'I feel like I'm in prison and I don't understand the crime,' she told him once the preliminaries were over.

'Wow! That sounds really heavy.'

'Yeah. It feels really heavy as a matter of fact.' (BNC)

(11') I feel as if I'm / was / were in prison...

(11") ? I feel as though I'm / was / were in prison...

(12) I felt like I was learning to walk again. (S. Brampton [2008: 4])

(13) I felt like I was a guinea pig, not a human being. (S. Brampton [2008: 213])

(13') I felt like a guinea pig, not a human being.

(13") I felt as if I was a guinea pig.

12 This analysis focuses on feel as an experiencer verb, I being the subject. However, it must be noted that feel like may be used with a subject that has a different semantic role:

(14) To me it felt like the total disintegration of everything I had ever known about myself. (S. Brampton [2008: 42])

It is anaphorical of mental pain or depression and it is thematized. The experiencer $m e$ is tropicalized by fronting but is presented as a witness of a change caused by depression. A comparable representation occurs in (15): depression is the cause of [I / feel like an invalid]. The $I$ experiencer, in object function, is acted upon by mental pain:

(15) It makes me feel like an invalid. (S. Brampton [2008: 88])

\subsection{Feel as if + propositional content}

14 As if connects a real experience of mental pain or depression to a hypothetical one: the subject's experience of pain is compared to an irreal situation which causes him or her an emotion similar to that caused by mental pain. In (16) and (17), the as if clause functions as predicative complement. The subject in the matrix and in the predicative complement 
coalesce in (16) whereas there is a metonymic relationship between I and my mind in (17). In (16) I feel... as if the room's closing on me, the subject of the matrix and that of the as if clause are distinct. In all these occurrences, the idea of comparison encoded by as if is not salient. It is more a question of shifting from comparison to evaluating how real the content of the as if clause is or feels like for the I. As if could be replaced by that as in (16') and (17'). The verb feel with a that-content clause as its direct object would then acquire a cognitive meaning, as is the case in (5'). As if, unlike that, reinforces the modal meaning, the irreal contained by the utterance (R. Huddleston \& G. Pullum [2002: 1151]):

(16) 'It's not as rational as that. I'm scared but I don't know what of. I feel as if I'm drowning, or as if the room's closing in on me. I feel as if I'll die if I stay where I am but I'm scared to get up and go somewhere else. It's awful, I can't explain it. (BNC)

$\left(16^{\prime}\right)$ [...] I feel that I'm drowning, or that the room's closing on me. I feel that I'll die.

(17) After he calmed down, Scott reasoned that if Annabel were having a heart attack, she wouldn't be able to talk on the telephone. Cautiously he said, 'Why do you think that, angel?'

'My heart is thumping! I can't breathe properly - I'm gasping for air!'

'It might be another anxiety attack,' Scott suggested gently.

Annabel said in an agitated voice, 'I feel as if my mind is whirling madly, like a hurricane. I can't control it. I feel taut and tense. I'm literally shaking!' ( $B N C)$

$\left(17^{\prime}\right)[\ldots]$ 'I feel that my mind is whirling madly, like a hurricane.

In (18) and (19), feel is used in the matrix in the past tense, V-ED, and so is the verb in the as if clause, due to tense cohesion in a past narrative. The modal value of -ED cannot be totally discarded, but it certainly does not prevail.

(18) I felt as if I lost my balance (S. Brampton [2008: 42])

(19) I felt, that year, as if my heart broke over and over again.

(S. Brampton [2008: 178])

In (20), the instanciation of WILL +-ED reinforces the epistemic modality, in the sense that the predicative relationships the world / sweep over and engulf are presented as irreal projections in the future as is shown in the manipulation in $\left(20^{\prime}\right)$ :

(20) After being and feeling a nothing and nobody, and forced into a continued state of physical and emotional submission, I felt as if the world would sweep over and engulf me, while I would meekly accept and act upon suggestions and orders from others, out of the habitual fear that had grown within me, in hospital. (J. Frame [1994: 224])

$\left(20^{\prime}\right)[\ldots]$ I feel as if the world will sweep over and engulf me...

In (21), the irreal dimension is primarily presented in an as if clause. In the utterance that follows, the conceptualizer comments upon it in an as though clause. With though, the main difference lies in that the content of the clause is not only presented as irreal but it is also suggested that it goes against what is likely to be. The clause entails that there is life ouside this one that I have found there:

(21) I feel as if I am poised somewhere on the edge of a slope, and about to slide down when I am supposed to be climbing up. It's crazy, but I feel as though I have no life outside this one I have found here, complete with silly old colonials and Masai witch-doctor. (BNC) 

enervation, but more particularly an odd fragility in (24) function as direct objects of feel. The as if clause does not have a predicative function as it is the case in the previous examples. The predication is oriented towards the object in an SVO construction. The manipulation with like is not receivable given that the adverbial clause in as if is in a relationship of dependency with the main predication I/feel myself dropping and I/feel a kind of numbness, an enervation, but more particularly an odd fragility, and not with the noun phrase which precedes it:

$\left(22^{\prime}\right) * \ldots$ and I feel myself dropping like a trap door had opened into darkness.

$\left(24^{\prime}\right){ }^{*}$ I felt a kind of numbness, an enervation, but more particularly an odd fragility, like my body had actually become frail, hypersensitive and somehow disjointed and clumsy, lacking normal coordination.

In the examples that follow, the construction differs and the comparison is no longer between the experiencer's feelings and a hypothetical situation but rather between two distinct situations or at least two distinct predications. In (22), S/P 1 I / feel myself dropping is compared to an external situation a trap door / open into darkness which is anterior to $\mathrm{S} /$ $\mathrm{P}$ 1. As if + HAD V-EN allows the I narrator to represent a present experience in terms of a past hypothetical one:

(22) ... and I feel myself dropping as if a trap door had opened into darkness. (J. Frame [2009: 18]) my treasures and glimpsing though the half-open door into the adjoining room the waiting coffin - my final burrow milk-white web nest between two rocks. (J. Frame [2009: 191-192])

felt a kind of numbness, an enervation, but more particularly an odd somehow disjointed and clumsy, lacking normal coordination. (W. Styron [1990: 43])

In (23) feel is followed by a predicative adjectival phrase and, here again, the manipulation with like is not receivable:

$\left(23^{\prime}\right) *$ I felt remote from the arrangements being made for me; like I were lying on my death-bed watching the invasion of my house and the disposal of my treasures... 
the irreal construction in like or as if, the experience of the $I$ is not denoted in its globality. It is referred to in terms of what it is not. In addition, the comparison allows to highlight a particular dimension which is made salient for both participants, the experiencer and the addressee.

\section{The irreal: figurative language, conceptual knowledge and the representation of mental pain} reality concerns what has not occurred and is recognized as such. The irreal allows the experiencer to represent and conceptualize his or her feelings, in an alternative way, which is not counterfactual. The elements of comparison are iconic of the mental pain feelings. The conceptualizer places his or her mental pain feelings outside conceived reality, in a region which is the irreal. The grounded mental pain feelings belong to the conceptualizer's inner reality, which is foregrounded thanks to figurative elements. [Like + complement] and [as if + clause] place mental pain feelings in a figurative irreality, which correlates the actual feelings of mental pain and their representations. The elements of comparison are based on the conceptualizer's mental constructions of what he or she feels. Expressions such as those used in (1) to (24) evoke a mental picture representing the actual feelings of the experiencer. They presuppose a mental construction describing the inherent nature of mental pain. The need for a schematic characterization of mental pain is answered thanks to the lexical verb feel and the figurative complements it governs. The complementation in like or as if in (1) to (21) does not introduce elements that are counter to the actual feeling. They indicate that mental pain can only be described by approximation, in terms of what it is not. The comparison or the comparative hypothetical situation introduced by as if turn out to be ways to conceptualize real pain by externalizing it from the real. In a note, R. Langacker [2008: 29] explains that "the 'world' includes both the real world and the mental worlds we construct, as well as the body and even our mental experience itself (to the extent that we can reflect on it, as opposed to merely undergoing it)." Feelings of mental pain are at the very core of the experiencer-cognizer's reality. To communicate about them, he or she situates them in a reality which is not fully established. R. Langacker [1991: 243] develops what he considers as unknown reality: "Observe that unknown reality is part of irreality of which the remainder constitutes non-reality."

The impossibility to express mental pain other than by comparing it with what it is not grants it an irreal dimension. Nevertheless, the verbalization of mental pain enables the experiencer-cognizer to give it a cognitive reality by representing it with words, images, situations. In that respect, linguistic expressions generate the irreal, potentially viewed as real. What is real or irreal depends on one's positioning towards a state of affairs, past, present or future. In the examples presented in this paper, mental pain is conceptualized in different ways: it may be figuratively represented as an entity, an agonistic force, or it may be conceived as a particular state, an emotional state or an event. Emotions and feelings can be represented either as states or events: $\mathrm{X}$ is in pain (state), $\mathrm{X}$ undergoes $\mathrm{Y}$ (e.g. $\mathrm{X}$ is sent into a frenzy), $\mathrm{Y}$ acts upon $\mathrm{X}$ (e.g. My depression drove me to commit suicide, pain ruled over me...). Mental pain is represented as a trap, a hole, hell, prison...; the detrimental experiencer as an invalid, an orphan, not a human being... A. Wierzbicka [1995], Z. Kövecses 
$[1990,2003]$ among others explain that "emotion terms have a great deal of conceptual content and structure" (Z. Kövecses [2003: 7]). R. Langacker [2008: 32] develops the idea that conceptual structure is both "propositional in nature" and that it has "an imagistic character". The conceptual structure of mental pain is constructed by the "vocabulary", the lexical verb feel in particular, by analogy with other entities and by the syntactic combination of the verb and its complementation. The co-constructional polysemy of feel makes it a good candidate to represent the complexity of the perceptual and emotional experience of mental pain in its multidimensionality. The expression of mental pain is primarily that of a single experiencer. However, verbal expression requires to take intersubjectivity into account. The individual expression of pain is such that it develops through and for communicative intentions. It includes a certain degree of conventionality, at the conceptual and the communicative levels.

Expressing one's feelings and emotions, and more specifically mental pain, relies on the verbal reconstruction of the quasi inexpressible. Mental pain can be conceptualized as a subtle emotional state (feel like + noun phrase) or as an emotional event (feel like / as if + propositional content). The conceptualization of mental pain encompasses novel and established representations. It is sensory and emotive, apprehended in context, personal and cultural. C. Lacassain-Lagoin [2012: 64], following Wittgenstein's approach, shows that both proposition and perception co-construct a model of reality in which truth and falsity co-exist and are, in all aspects, comparable. Mental pain exists and yet what is referred to linguistically "is often a virtual (or fictive) instance, i.e. an imaginary instance 'conjured up' for some purpose." (R. Langacker [2008: 36]) Mental pain can be seen as a perceptive and emotional experience. The perception of the subject by himself or herself, the interpretation of reality by the subject and the interpretation of the language of mental pain both by the subject and the reader are intertwined in discourse about mental pain. By reporting mental pain (emotional states or events), the conceptualizer evokes feelings in the reader. Writing about one's mental pain serves the expressive function of language but not exclusively. Implicit communicative interaction, interpretative and cognitive dimensions are also at play: by expressing one's pain and communicating about it, the experiencer may gain a better understanding of it. Verbalizing mental pain is a volitional act and as such it may enable the experiencer to act upon himself or herself and his or her feelings.

\section{Conclusion}

As stated by K. Linquist, A. Satpute, Ajay \& M. Gendron [2015], "language helps constitute emotion perception". It has a constitutive role in perceiving mental pain as what it is not, as what it feels like. With constructions such as feel like, feel as if, conceptual knowledge is used to represent and, to some extent, to make sense of mental pain. Mental pain occurs in contexts when the self is threatened, fragmented, humiliated. Pain is felt within, it comes from within or from an external stimulus. The sensation experienced inside one's body is conceptualized and shared through language. The difficulty lies in this: once it is put into words, mental pain is no longer what it is: it is represented in terms of what it is not. However, the irreal dimension of its representation grants it an existence for the outside world and a form of objectivization for the self. Putting mental pain into words forces the experiencer to externalize it, to some extent. Verbal expression constructs the emotion, the feeling, through elements of comparison, and, in return, words modulate 
them. The irreal, the elements of comparison, come to the rescue of the conceptualization of what is most real: inner mental pain. In that respect, figurative language, which is central for human conceptualization, (re)creates the emotional reality of mental pain. In addition, putting words on the pain which is felt may reduce the intensity of the emotional experience. The act of using language to represent feelings and emotions of mental pain may detach the subject from the impact of the experience and, as a consequence, may reduce the intensity of the emotional experience. To establish intersubjective communication, a certain degree of conventionality needs to be maintained. Furthermore, emotional intersubjectivity, sharing or writing about one experience of mental pain, enables the subject to transform his or her private experience into a common experience.

\section{BIBLIOGRAPHY}

DAMASIO Antonio R., 1999, The Feeling of What Happens, London: Heineman.

DAMASIO Antonio R., 1994, Descartes' Error. Emotion, Reason and the Human Brain, New York: Avon Books.

GENDRON Maria, LINDQUIST Kristen A., BARSALOU Lawrence \& BARRETT Lisa F., 2012, "Emotion words shape emotion percepts", in PIETROMONAco Paula R (ed.), Emotion 12(2), American Psychological Association, Washington D.C, 314-325.

GISBORNE Nikolas, 2010, The Event Structure of Perception Verbs, Oxford: Oxford University Press. HUDDLESTON Rodney \& PULLUM Geoffrey K., 2002, The Cambridge Grammar of the English Language, Cambridge: Cambridge University Press.

KOVECSES Zoltán, 2003, Metaphor and Emotion. Language, Culture, and Body in Human Feeling, Cambridge: Cambridge University Press.

LACASSAIN-LAGoIN Christelle, 2012, «Perception, folie et langage : le compte rendu de perception de la "réalité du fou" ", in MARIE Florence (ed.), Le fou - Cet Autre, Mon Frère, Rives, Cahiers de l'Arc Atlantique, numéro 7, Paris : L'Harmattan, 59-81.

LANGACKER Ronald W., 1991, Foundations of Cognitive Grammar. Descriptive application, Vol. 2, Stanford: Stanford University Press.

LANGACKER Ronald W., 2008, Cognitive Grammar. A Basic Introduction, Oxford: Oxford University Press.

LASCARATOU Chryssoula, 2007, The Language of Pain, Amsterdam/Philadelphia: John Benjamins. LINDQUIST, Kristen A, SATPUTE Ajay B., GENDRON Maria, 2015, "Does language do more than communicate emotion?", Current directions in psychological science 24,2, 99-108.

MERSKEY Harold \& BOGDUK Nikolai (eds.), 1994 [2 ${ }^{\text {nd }}$ edn], "Part III: Pain Terms, A Current List with Definitions and Notes on Usage", Classification of Chronic Pain: Descriptions of Chronic Pain Syndromes 
and Definitions of Pain Terms, IASP Task Force on Taxonomy, Seattle: IASP Press, also available at: http://www.iasp-pain.org/terminology?navitemNumber=576

PAULIN Catherine, 2003, «Polysémie et complémentation verbale : le verbe feel dans tous ses états ", in DELMAS Claude (ed.), Correct, incorrect en linguistique anglaise, C.I.E.R.E.C., Travaux 113, Saint-Étienne : Publications de l'Université de Saint-Étienne, 129-155.

PAULIN Catherine, 2018, «L'écriture de soi : genres discursifs, mode discursif ? Le récit des internements de Janet Frame : Faces in the Water, An Autobiography ", in soRLIN Sandrine (ed.), Études de Stylistique Anglaise 12, Lyon : Université Jean Moulin Lyon 3, 269-289.

ROSCH Eleanor, 1978, “Principles of categorization”, in ROSCH Elenanor \& LLOYD Barbara B. (eds.), Cognition and categorization, Hillsdale, NJ: Erlbaum, 28-49.

WIERZBICKA Anna, 1999, Emotions Across Languages and Cultures. Diversity and Universals, Cambridge: Cambridge University Press.

\section{Corpus}

BRAMPTON Sally, 2008, Shoot the Damn Dog. A Memoir of Depression, London: Bloomsbury Publishing. FRAME Janet, 2009 [1961], Faces in the Water, London: Virago Press.

FRAME Janet, 1994 [1991], An Autobiography. New York: George Brazillier.

PLATH Sylvia, 1971, The Bell Jar, London: Harper Collins Publishers.

PLATH Sylvia, 2014, The Journals of Sylvia Plath, KUKIL Karen (ed.), London: Faber and Faber.

STYRON William, 1990, Darkness Visible: A Memoir of Madness, New York: Random House.

\section{NOTES}

1. I owe some of the examples quoted in this paper to a former M2 student, Elina Aristodemou. Many thanks to her.

2. $C$ for cognizer.

3. The BNC excerpts are taken from contemporary autobiographical discourse genres.

\section{ABSTRACTS}

In this article, I am interested in the relationship between the experience of mental pain, the sensations and emotions it engenders and its verbal representations in autobiographical writings. I have attempted to provide an account of the verbalization of mental pain by analyzing the constructions feel like + NP, feel like / as if + propositional content. These constructions enable the subject to represent his or her experience in terms of an irreal experience and, by mobilizing a comparison, to highlight an important aspect of mental pain.

Cet article analyse les relations entre l'expérience de la douleur mentale, les sensations et les émotions qu'elle entraîne et les représentations qui en sont faites dans des écrits autobiographiques. L'étude du verbe lexical feel dans les constructions feel like + SN, feel like / as if 
+ contenu propositionnel permet de montrer que la douleur mentale est conceptualisée comme ce qu'elle n'est pas, dans l'irréel. En mobilisant un élément de comparaison, l'énonciateur rend saillant un aspect important de la douleur mentale.

INDEX

Keywords: experience of mental pain, verbal dimension of mental pain, percepts, feelings, emotions, feel, feel like, feel as if, figurative language, the irreal, autobiographical writings Mots-clés: expérience de la douleur mentale, verbalisation de la douleur mentale, percepts, sensations, émotions, feel, feel like, feel as if, langage figuré, irréel, écrits autobiographiques

\section{AUTHOR}

\section{CATHERINE PAULIN}

Université de Strasbourg, LiLPa - EA 1339 (Linguistique, Langues et Parole)

cpaulin@unistra.fr 